\title{
Preservation by lactic fermentation and physicochemical characterization of okra produced underwater salinity and potassium fertilization
}

\section{Conservação láctica e caracterização físico-química do quiabo produzido sob salinidade da água e adubação potássica}

\author{
Lauriane Almeida dos Anjos Soares ${ }^{1 *}$; Rafael Gonçalves da Silva ${ }^{2}$; \\ Geovani Soares de Lima3; Giuliana Naiara Barros Sales"; \\ Franciscleudo Bezerra da Costa ${ }^{5}$; Alzira Maria de Sousa Silva Neta ${ }^{4}$; \\ Rômulo Carantino Lucena Moreira ${ }^{6}$, Josivanda Palmeira Gomes ${ }^{7}$
}

\section{Highlights:}

Irrigation water salinity negatively affects the quality of okra fruits.

Incremental doses of potassium minimize the deleterious effects of irrigation water salinity.

Lactic fermentation promotes higher titratable acidity and soluble solids content in okra fruits.

\begin{abstract}
The use of saline water in agricultural production will be increasingly necessary in the next decades. However, postharvest quality may be compromised, as in okra, due to salt stress and/or factors inherent to storage and transportation. In this context, developing alternative methods of preservation, including lactic fermentation, may be a promising way to maintain and even improve the nutritional quality of okra. Thus, the objective was to evaluate the production components of okra subjected to different levels of water salinity and doses of potassium fertilization, and further to evaluate the preservation by lactic fermentation of okra fruits produced under water salinity. The first experiment was carried out in lysimeters under field conditions in Neossolo Regolitico (Psamment) of sandy loam texture in Pombal-PB, in a randomized block design in a $5 \times 5$ factorial scheme, testing 5 levels of irrigation water salinity $\left(0.3 ; 1.3 ; 2.3 ; 3.3\right.$, and $\left.4.3 \mathrm{dS} \mathrm{m}^{-1}\right)$ and 5 doses of potassium fertilization $(75 ; 112.5 ; 150$; 187.5 , and $225 \mathrm{mg}$ of $\mathrm{K}_{2} \mathrm{O} \mathrm{kg}^{-1}$ of soil), with three replicates. After that, the okra fruits produced under the different salinity levels were stored in six mixtures of salts present in lactic fermentation brine (100-0-0, 0-100-0, 0-0-100, 50-50-0, 0-50-50, and 50-0-50 of $\mathrm{NaCl}, \mathrm{CaCl}_{2}$ and $\mathrm{KCl}$, respectively), under a $5 \times 6$ factorial, with three replicates, in a completely randomized design. The post-harvest quality, after fermentation, was evaluated based on their physicochemical characteristics. Irrigation
\end{abstract}

\footnotetext{
${ }_{1}$ Profa, Unidade Acadêmica de Ciências Agrárias, Universidade Federal de Campina Grande, UFCG, Pombal, PB, Brasil. E-mail: lauriane.soares@pq.cnpq.br

2 Discente do Curso de Graduação em Agronomia, UFCG, Centro de Ciências e Tecnologia Agroalimentar, Pombal, PB, Brasil. E-mail: rafaelgoncalvesdasilva@hotmail.com

3 Prof. Visitante, Unidade Acadêmica de Ciências Agrárias, UFCG, Pombal, PB, Brasil. E-mail: geovani.soares@pq.cnpq.br

4 Discentes do Curso de Mestrado do Programa de Pós-graduação em Horticultura Tropical, UFCG, Pombal, PB, Brasil. E-mail: giulianasales@outlook.com; alziraufcg@gmail.com

5 Prof., Unidade Acadêmica de Tecnologia de Alimentos, UFCG, Pombal, PB, Brasil. E-mail: franciscleudo@yahoo.com.br

6 Discente do Curso de Doutorado do Programa de Pós-Graduação em Engenharia Agrícola, UFCG, Campina Grande, PB, Brasil. E-mail: romulocarantino@gmail.com

7 Prof ${ }^{a}$, Unidade Acadêmica de Engenharia Agrícola, UFCG, Campina Grande, PB, Brasil. E-mail: josivanda@gmail.com

" Author for correspondence
} 
water salinity negatively affected the average length, average weight, titratable acidity, soluble solids/ titratable acidity ratio, and $\mathrm{pH}$ of the okra fruits. Potassium doses increased the average diameter of okra fruits, minimizing the deleterious effects of irrigation water salinity. The vitamin $\mathrm{C}$ contents of pickled okra fruits were not compromised by salt stress. Among the lactic fermentation brines, the formulation containing the proportion $\mathrm{NaCl}: \mathrm{CaCl}_{2}$ stands out as promoting the highest titratable acidity and soluble solids content in pickled okra fruits.

Key words: Abelmoschus esculentus. Salinity. Potassium. Storage.

\section{Resumo}

O uso de águas salinas na produção agrícola será cada vez mais necessário nas próximas décadas, entretanto, a qualidade pós-colheita, como no quiabeiro, pode ser comprometida devido ao estresse salino e/ou fatores inerentes ao armazenamento e transporte; neste sentido, o desenvolvimento de métodos alternativos de conservação, dentre eles a fermentação láctica pode constituir uma via promissora para manter e até melhorar a qualidade nutricional do quiabeiro. Assim, objetivou-se avaliar os componentes de produção do quiabeiro submetido a diferentes salinidades da água e doses de adubação potássica; visou-se, também, avaliar a conservação por fermentação láctica dos frutos do quiabeiro produzidos sob salinidade da água. O primeiro experimento foi desenvolvido em lisímetros sob condições de campo em Neossolo Regolítico de textura franco-arenosa em Pombal-PB. Adotou-se o delineamento em blocos casualizados em esquema fatorial $5 \times 5$, testando 5 níveis de salinidade da água de irrigação $(0,3$; 1,$3 ; 2,3 ; 3,3$ e $\left.4,3 \mathrm{dS} \mathrm{m}^{-1}\right)$ e 5 doses de adubação potássica $\left(75 ; 112,5 ; 150 ; 187,5\right.$ e $225 \mathrm{mg}$ de $\mathrm{K}_{2} \mathrm{O}$ $\mathrm{kg}^{-1}$ de solo) com três repetições. Em seguida os frutos de quiabeiro produzidos sob os distintintos níveis salinos foram armazenados em seis misturas de sais presentes na salmoura de fermentação láctica (100-0-0, 0-100-0, 0-0-100, 50-50-0, 0-50-50 e 50-0-50 de $\mathrm{NaCl}, \mathrm{CaCl}_{2}$ e $\mathrm{KCl}$, respectivamente), sob fatorial $5 \times 6$, com três repetições, no delineamento inteiramente casualizado, cuja qualidade póscolheita, após o processo de fermentação, foi avaliada mediante as características físico-químicas dos frutos de quiabeiro. A salinidade da água de irrigação afetou negativamente o comprimento médio, peso médio, acidez titulável, razão de sólidos solúveis/acidez titulável e $\mathrm{pH}$ dos frutos de quiabeiro. As doses de potássio provocam acréscimos no diâmetro médio de frutos do quiabeiro minimizando os efeitos deletérios da salinidade da água de irrigação. Os teores de vitamina $\mathrm{C}$ dos frutos de quiabeiro em conserva não foram comprometidos pelo estresse salino. Dentre as salmouras de fermentação láctica, a formulação contendo a proporção de $\mathrm{NaCl}: \mathrm{CaCl}_{2}$ destaca-se com maior acidez titulável e sólidos solúveis dos frutos do quiabeiro em conserva.

Palavras-chave: Abelmoschus esculentus. Salinidade. Potássio. Armazenamento.

\section{Introduction}

Okra, Abelmoschus esculentus (L.), is an annual vegetable of the Malvaceae family native to Africa. Its fruit is a fibrous capsule of intense green color full of round white seeds. Okra has a fast vegetative cycle, easy cultivation, and offers high profitability. In 2017, the value of a ton of okra ranged from US \$236.8 to US \$3,870.6 worldwide (Food and Agriculture Organization of the United Nations [FAOSTAT], 2017). It is a very popular vegetable in semi-arid regions, such as in northeastern Brazil, due to its rusticity and tolerance to high temperatures, and not requiring advanced technology in its cultivation (Abubaker, Ahadi, Shuang-En, \& Guang-Cheng, 2014).

However, the scarcity of water resources in arid and semi-arid regions involves both quantitative and qualitative aspects, causing restrictions in their use for human consumption, animal consumption, and irrigation. In these regions, it is still common to find water sources with a high concentration of salts, mainly sodium, which limits their use in agriculture (Mermoud, Tamini, \& Yacouba, 2005; Neves et al., 2009). Being an irrigation-dependent 
crop, the use of water with high salinity can limit the growth and productivity of okra. In general, this is due to the reduction in the osmotic potential of the soil solution and may also cause ionic effects, such as toxicity and nutritional imbalance (Garg \& Bhandari, 2016; Islam, Islam, \& Biswas, 2017).

However, plants have developed a wide range of mechanisms to withstand a variety of stress conditions. It has been demonstrated that minerals, particularly potassium, play a fundamental role in their resistance to salt stress, and this tolerance to salinity is directly associated with the $\mathrm{K}^{+}$content due to its involvement in osmotic regulation and competition with $\mathrm{Na}^{+}$(Marschner, 2012; Abbasi et al., 2014). Among vegetables, okra is highly demanding in terms of fertilization, and potassium is one of the most extracted nutrients from the soil (Mandal, Singh, Singh, \& Roy, 2012).

Another aspect to be emphasized is post-harvest quality, because the fruit is highly perishable soon after harvest, due to its high respiratory metabolism (Freitas et al., 2015). Therefore, the post-harvest preservation period of okra is very short, especially under storage conditions with high temperatures and low relative humidity, which accelerate water loss, depreciating the commercial value of fruits for fresh consumption (Finger, Della-Justina, Casali, \& Puiatti, 2008).

In this context, understanding the physical and chemical events that occur in okra fruits and their application may contribute to the preservation and expansion of the supply of high-quality products with longer duration. One of the techniques that can be used for the postharvest preservation of okra fruits is lactic fermentation, a process in which bacteria, fungi, and yeasts alter the structure of foods or improve their taste characteristics, even extending their shelf life, for instance, preserved vegetable products like olives and pickles (Di Cagno, Coda, De Angelis, \& Gobbetti, 2013). In agriculture, preservation by lactic fermentation emerges as an alternative for the control of enteric pathogens, reducing the growth of pathogens in cereals, fruits, and vegetables (Nguyen, Dong, Nguyen, \& Lee, 2015; Li et al., 2015).

The objective of this study was to evaluate the production components of okra subjected to different levels of water salinity and doses of potassium fertilization, as well as analyzing the preservation by lactic fermentation in the postharvest quality of okra fruits irrigated with saline waters.

\section{Material and Methods}

The study was conducted in two stages, at the Center for Sciences and Agri-food Technology - CCTA, of the Federal University of Campina Grande - UFCG, located in the municipality of Pombal, PB, Brazil (647’20" S; 3748’01” W, 194 $\mathrm{m}$ a.s.1). The first stage was carried out in the field, subjecting okra plants to different levels of water salinity and doses of potassium fertilization, while the second stage was conducted to evaluate different mixtures of salts present in the lactic fermentation brine during the postharvest preservation of okra fruits produced under conditions of high salinity of irrigation water.

\section{Field experiment}

For the first stage, the experimental design was randomized blocks, with treatments arranged in a $5 \times 5$ factorial scheme with three replicates, and the experimental plot consisted of one plant per pot. The treatments resulted from the combination of five levels of irrigation water salinity - ECw $\left(0.3 ; 1.3 ; 2.3,3.3\right.$, and $\left.4.3 \mathrm{dS} \mathrm{m}^{-1}\right)$ and five doses of potassium fertilization (K1-75; K2-112.5; K3150; K4-187.5, and $\mathrm{K} 5-225 \mathrm{mg}$ of $\mathrm{K}_{2} \mathrm{O} \mathrm{kg}^{-1}$ of soil), based on the potassium fertilization recommended for pot experiments according to Novais, Neves and Barros (1991).

Okra plants, cv. Santa Cruz, were grown in plastic containers (pots) with approximately $20 \mathrm{~L}$ 
capacity $(35 \mathrm{~cm}$ height x $31 \mathrm{~cm}$ upper diameter x 20 $\mathrm{cm}$ lower diameter), lined at the base with geotextile to avoid loss of soil material, and filled with a $3-\mathrm{cm}-$ thick layer of crushed stone. A transparent hose was connected to the base of each pot to facilitate drainage and to a 2.0-L container to collect the drained water. Then, each pot was filled with $24.5 \mathrm{~kg}$ of material of a Neossolo Regolítico Eutrófico (Psamment), with sandy loam texture (collected at 0-20 cm depth), with loamy sand textural classification, previously pounded to break up clods and sieved. Its physicalhydraulic and chemical attributes, determined in the laboratory prior to sowing in the two experiments, are shown in Table 1.

\section{Table 1}

Chemical and physical characteristics of the soil used in the experiment

\begin{tabular}{|c|c|c|c|c|c|c|c|c|}
\hline \multicolumn{9}{|c|}{ Chemical characteristics } \\
\hline $\left.\mathrm{pH} \mathrm{H}_{2} \mathrm{O}\right)$ & $\mathrm{OM}$ & $\mathrm{P}$ & $\mathrm{K}^{+}$ & $\mathrm{Na}^{+}$ & $\mathrm{Ca}^{2+}$ & $\mathrm{Mg}^{2+}$ & $\mathrm{Al}^{3+}$ & $\mathrm{H}^{+}$ \\
\hline$(1: 2.5)$ & $\mathrm{g} \mathrm{kg}^{-1}$ & $\left(\mathrm{mg} \mathrm{kg}^{-1}\right)$ & \multicolumn{6}{|c|}{ 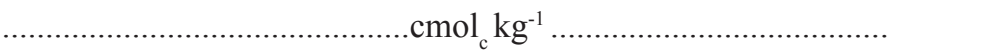 } \\
\hline 5.58 & 2.93 & 39.20 & 0.23 & 1.64 & 9.07 & 2.78 & 0.00 & 8.61 \\
\hline \multicolumn{9}{|c|}{.......... Chemical characteristics............. } \\
\hline \multirow{2}{*}{$\begin{array}{c}\mathrm{EC}_{\mathrm{se}} \\
\left(\mathrm{dS} \mathrm{m}^{-1}\right)\end{array}$} & CEC & SAR & ESP & \multicolumn{3}{|c|}{ Size fraction $\left(\mathrm{g} \mathrm{kg}^{-1}\right)$} & \multicolumn{2}{|c|}{ Water content $\left(\right.$ dag $\left.\mathrm{kg}^{-1}\right)$} \\
\hline & $\mathrm{cmol}_{\mathrm{c}} \mathrm{kg}^{-1}$ & $\left(\mathrm{mmol} \mathrm{L}^{-1}\right)^{0,5}$ & $\%$ & Sand & Silt & Clay & $33,42 \mathrm{kPa}^{1}$ & $1519,5 \mathrm{kPa}^{2}$ \\
\hline 2.15 & 22.33 & 0.67 & 7.34 & 572.70 & 100.70 & 326.60 & 25.91 & 12.96 \\
\hline
\end{tabular}

pH -Hydrogen potential, OM -Organic matter: Walkley-Black Wet Digestion; $\mathrm{Ca}^{2+}$ and $\mathrm{Mg}^{2+}$ extracted with $1 \mathrm{M} \mathrm{KCl}$ at $\mathrm{pH} 7.0 ; \mathrm{Na}^{+}$ and $\mathrm{K}^{+}$extracted with $1 \mathrm{M} \mathrm{NH}_{4} \mathrm{OAc}$ at $\mathrm{pH} 7.0 ; \mathrm{Al}^{3+}+\mathrm{H}^{+}$extracted with $0.5 \mathrm{M} \mathrm{CaOAc}$ at $\mathrm{pH} 7.0 ; \mathrm{EC}_{\mathrm{se}}$ - Electrical conductivity of the saturation extract; CEC - Cation exchange capacity; SAR -Sodium adsorption ratio of the saturation extract; ESP - Exchangeable sodium percentage; ${ }^{1}$ field capacity; ${ }^{2}$ permanent wilting point.

Basal fertilization with nitrogen and potassium was performed as recommended for pot experiments by Novais et al. (1991), applying 100 and $300 \mathrm{mg}$ $\mathrm{kg}^{-1}$ of soil of nitrogen and phosphorus, respectively, in the forms of urea and monoammonium phosphate (MAP), applied via irrigation water at 20,30, and 40 days after sowing (DAS). Potassium fertilization was split into four applications via fertigation, at 10-day intervals from $20 \mathrm{DAS}$, with an amount of $150 \mathrm{mg} \mathrm{K} \mathrm{O} \mathrm{kg}^{-1}$ of soil per container in the $\mathrm{K} 3$ treatment, using potassium chloride. The amounts of fertilizer in the other treatments were calculated based on the K3 dose. The pots were arranged in single rows spaced $1 \mathrm{~m}$ apart with spacing of $0.6 \mathrm{~m}$ between plants in the row.

The water used in irrigation with the lowest electrical conductivity $\left(\mathrm{ECW}=0.3 \mathrm{dS} \mathrm{m}{ }^{-1}\right)$ came from the public supply system; for the other levels, the water was prepared in order to have an equivalent proportion of $7: 2: 1$ of $\mathrm{Na}: \mathrm{Ca}: \mathrm{Mg}$, respectively, based on the methodology contained in Richards (1954). Five seeds were sown per pot at $3 \mathrm{~cm}$ depth with soil moisture at the level of field capacity in all experimental units, with low-salinity water $(0.3 \mathrm{dS}$ $\mathrm{m}^{-1}$ ) until the production of the first true leaf, when the treatments began to be applied. Thirty days after sowing, thinning was performed, keeping only one plant per pot.

Irrigations were performed daily at $17 \mathrm{~h}$. The volume applied in each irrigation event was estimated by water balance, based on the terms of the equation: $\mathrm{WC}=(\mathrm{Va}-\mathrm{Vd}) /(1-\mathrm{LF})$, where $\mathrm{WC}$ is water consumption, considering the volume of water applied to plants (Va) in the previous day, $\mathrm{Vd}$ is the volume drained, quantified in the morning of the next day, and LF is the leaching fraction, estimated at $20 \%$ every 15 days. 
Okra fruits were harvested from each plant as they reached the harvest point, which occurred between 4 and 5 days after anthesis, when the fruits were approximately $25 \%$ of their maximum size (Mota, Finger, \& Casali, 2000), and evaluated for average fruit length $(\mathrm{cm})$, average fruit diameter $(\mathrm{mm})$, and average fruit weight $(\mathrm{g})$. From harvest, fruits that showed no physical damage, insect attack, or visual presence of microorganisms were selected. After washing and sanitization (100 ppm of $\mathrm{NaClO}$ ), the fruits were subjected to spontaneous lactic fermentation in brine (Goldoni, 2007).
Analyses of okra fruits subjected to lactic fermentation

In this second stage, the variations in salt mixtures in the lactic fermentation process were evaluated in the preservation of okra fruits harvested from plants subjected to different salinity levels. The fermentation brine formulations were defined by mixing three components (Table 2), totaling six types of salt mixtures, according to BautistaGallego, López-López and Garrido-Fernández (2011), with modifications in concentrations. The total sum of the components in the mixtures $(100 \%)$ was equivalent to the proportion of $\mathrm{NaCl}(10 \%)$ in fermentation brine normally used in the industrial production of fermented green olives.

Table 2

Mixtures of salts present in the lactic fermentation brine of okra fruits. Pombal, PB

\begin{tabular}{cccc}
\hline \multirow{2}{*}{ Formulations } & \multicolumn{3}{c}{ Brine concentration $\left(\mathrm{g} \mathrm{L}^{-1}\right)$} \\
\cline { 2 - 4 } & $\mathrm{NaCl}$ & $\mathrm{CaCl}_{2}$ & $\mathrm{KCl}$ \\
\hline 1 & 100 & 0 & 0 \\
2 & 0 & 100 & 0 \\
3 & 0 & 0 & 100 \\
4 & 50 & 50 & 0 \\
5 & 0 & 50 & 50 \\
6 & 50 & 0 & 50 \\
\hline
\end{tabular}

Salinity levels were the same as in the previous experiment. The data were analyzed in a completely randomized experimental design, in a $5 \times 6$ factorial scheme, with five levels of water electrical conductivity and six combinations of salts in the preservation by lactic fermentation. To perform the physicochemical analyses, the fruits were processed in a domestic blender, with the addition of brine. The extract obtained was evaluated for the following variables: titratable acidity (\% citric acid), soluble solids (\%), vitamin C (mg $\left.100 \mathrm{~mL}^{-1}\right)$, soluble solids/titratable acidity ratio (SS/TA), and hydrogen potential $(\mathrm{pH})$.
Titratable acidity was determined in triplicate from a $10-\mathrm{mL}$ aliquot of extract, which was mixed with $40 \mathrm{~mL}$ of distilled water and 3 drops of alcoholic phenolphthalein at $1.0 \%$. Then, titration was performed up to the turning point with a previously standardized $\mathrm{NaOH}$ solution $(0.1 \mathrm{~N})$. The content of total soluble solids was determined in a digital refractometer with automatic temperature compensation. Vitamin $\mathrm{C}$ content was determined by the colorimetric method with 2,4-dinitrophenylhydrazine, according to the methodology proposed by Strohecker and Henning (1967). The soluble solids/titratable acidity ratio 
was obtained by dividing the values of soluble solids by the values of titratable acidity. The hydrogen potential was determined in the extract, using a digital potentiometer.

The data obtained were evaluated through analysis of variance by $F$ test. In cases of significance, linear and polynomial regressions were performed for the isolated factors (salinity levels and potassium doses) and Tukey test $(\mathrm{p}<0.05)$ was performed for the combinations of salt mixture in the lactic fermentation (Ferreira, 2011).

\section{Results and Discussion}

Based on the analysis of variance, the interaction between levels of irrigation water salinity and fertigation with different potassium doses had a significant effect only on the average fruit diameter (AFD) $(p<0.05)$. For the simple effects, the different levels of salinity had significant influence on all variables analyzed, for the average fruit length (AFL) and average fruit weight (AFW), $\mathrm{p}<0.01$ and $p<0.05$, respectively. There was no effect of the different potassium doses on the variables analyzed (Table 3).

Table 3

Summary of the analysis of variance for average fruit length (AFL), average fruit diameter (AFD), and average fruit weight (AFW) of fresh okra subjected to different levels of irrigation water salinity and potassium doses. Pombal, PB

\begin{tabular}{lcccc}
\hline \multirow{2}{*}{ Source of variation } & DF & \multicolumn{3}{c}{ Mean squares } \\
\cline { 3 - 4 } & & AFL & AFD & AFW \\
\hline Saline levels (S) & 4 & $23.028^{* *}$ & $6.754^{* *}$ & $518.631^{*}$ \\
$\quad$ Linear regression & 1 & $84.030^{* *}$ & $24.088^{* *}$ & $108.392^{\text {ns }}$ \\
Quadratic regression & 1 & $6.593^{*}$ & $0.762^{\text {ns }}$ & $1106.350^{*}$ \\
K dose (K) & 4 & $4.835^{\text {ns }}$ & $0.724^{\text {ns }}$ & $181.830^{\text {ns }}$ \\
$\quad$ Linear regression & 1 & $3.016^{\text {ns }}$ & $0.503^{\text {ns }}$ & $152.167^{\text {ns }}$ \\
Quadratic regression & 1 & $2.814^{\text {ns }}$ & $2.036^{\text {ns }}$ & $66.192^{\text {ns }}$ \\
Interaction (S x K) & 16 & $1.068^{\text {ns }}$ & $1.288^{*}$ & $137.276^{\text {ns }}$ \\
Blocks & 2 & $20.633^{\text {ns }}$ & $30.306^{\mathrm{ns}}$ & $250.367^{\text {ns }}$ \\
Residual & 48 & 1.437 & 0.671 & 209.648 \\
CV (\%) & & 7.87 & 4.54 & 23.83 \\
Overall Average & & 15.228 & 18.056 & 27.289 \\
\hline
\end{tabular}

ns, $* * *$ respectively not significant, significant at $\mathrm{p}<0.01$ and $\mathrm{p}<0.05$; DF -Degree of freedom; CV -Coefficient of variation.

Regardless of the potassium dose adopted in fertigation, the average length of okra fruits (Figure 1A) progressively decreased with the increase in the electrical conductivity of the water used, with the highest values of fruit length $(16.37 \mathrm{~cm})$ obtained in plants subjected to the lowest salinity level $(0.3 \mathrm{dS}$ $\mathrm{m}^{-1}$ ) and decreasing from this point, with a minimum value of $13.37 \mathrm{~cm}$ in okra fruits irrigated with $4.3 \mathrm{dS}$ $\mathrm{m}^{-1}$, i.e., a decrease of $18.32 \%$ between these salinity levels. However, the data are within normality, since the industrial and commercial preference is oriented to okra fruits with average length ranging from 8.9 to $12.7 \mathrm{~cm}$, and the okra fruits produced under the different levels of water salinity are all suitable for commercialization (Oliveira, Mugridge, Chaves, Mascheroni, \& Viña, 2012). 
According to the regression equations (Figure 1B), the average fruit diameter (AFD) in okra plants fertilized with 75,100 , and $125 \mathrm{mg} \mathrm{kg}^{-1}$ of $\mathrm{K}$ increased linearly by $2.28 \%, 5.20 \%$, and $3.34 \%$ per unit increase in $\mathrm{ECw}$, i.e., increments of $9.14 \%$, $20.8 \%$, and $13.36 \%$ in the AFD of plants subjected to $\mathrm{ECw}$ of $4.3 \mathrm{dS} \mathrm{m}^{-1}$ compared to those irrigated with $0.3 \mathrm{dS} \mathrm{m}^{-1}$ water. Regarding potassium doses of 50 and $150 \mathrm{mg} \mathrm{kg}^{-1}$, the model fitted to the data was quadratic, and plants that received these $\mathrm{K}$ doses and were under irrigation with 2.5 and $2.8 \mathrm{dS}$ $\mathrm{m}^{-1}$ water had the highest values of AFD, 19.56 and $19.33 \mathrm{~mm}$, respectively. According to Medeiros, Santos, Câmara and Negreiros (2008), potassium influences fruit postharvest quality due to several of its functions in plants, such as maintenance of ionic balance and cell turgor, control of stomatal opening and closure, synthesis and degradation of starch, and transport of carbohydrates through the phloem. In addition, the average fruit diameter for the different $\mathrm{K}$ doses as a function of the levels of electrical conductivity was $18.11 \mathrm{~mm}$, higher values than those obtained by Biswas, Hossain, Alam, Islam and Biswas (2016), who evaluated seven okra genotypes for production potential and nutritional quality, and obtained fruit diameters ranging from 17.8 to $15.1 \mathrm{~mm}$ in the genotypes Arka Anamika and Raja, respectively.
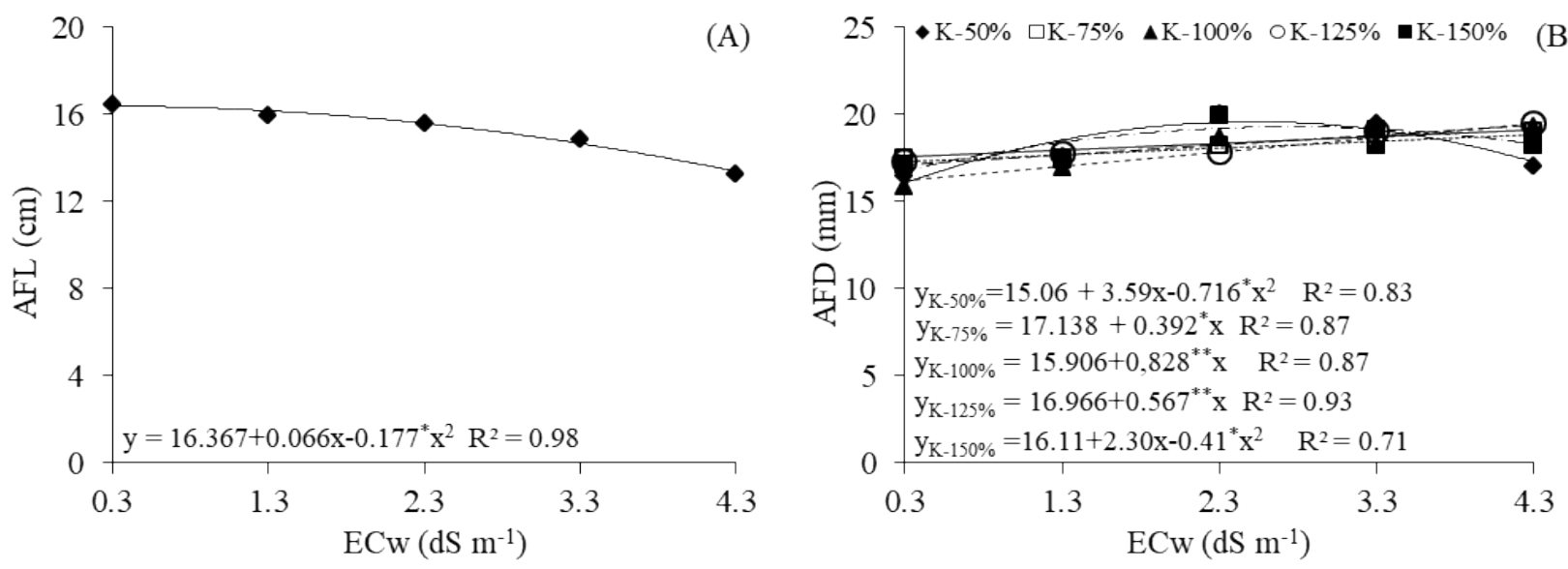

Figure 1. Average fruit length (AFL) of okra as a function of the electrical conductivity of irrigation water (ECw) (A), and average fruit diameter (AFD) of okra as a function of the electrical conductivity of irrigation water (ECw) and potassium doses (B). Pombal, PB.

According to the regression equation, the water salinity levels caused a quadratic response in average fruit weight (AFW) (Figure 2), with the highest value $(33.64 \mathrm{~g})$ at a salinity of $2.4 \mathrm{dS}$ $\mathrm{m}^{-1}$. Okra average fruit weight can be affected by irrigation water salinity, because this characteristic is directly associated with the fruit fresh mass, which decreases as salinity increases (Dias et al., 2011).
Azeem, Wu, Xing, Javed and Ullah (2017) explain that certain physiological processes, for example, a reduction in photosynthetic efficiency, stomatal conductance, and transpiration rates in okra plants, which are sensitive to the effects of salts, lead to reductions in growth rate, biomass production, and yield. 

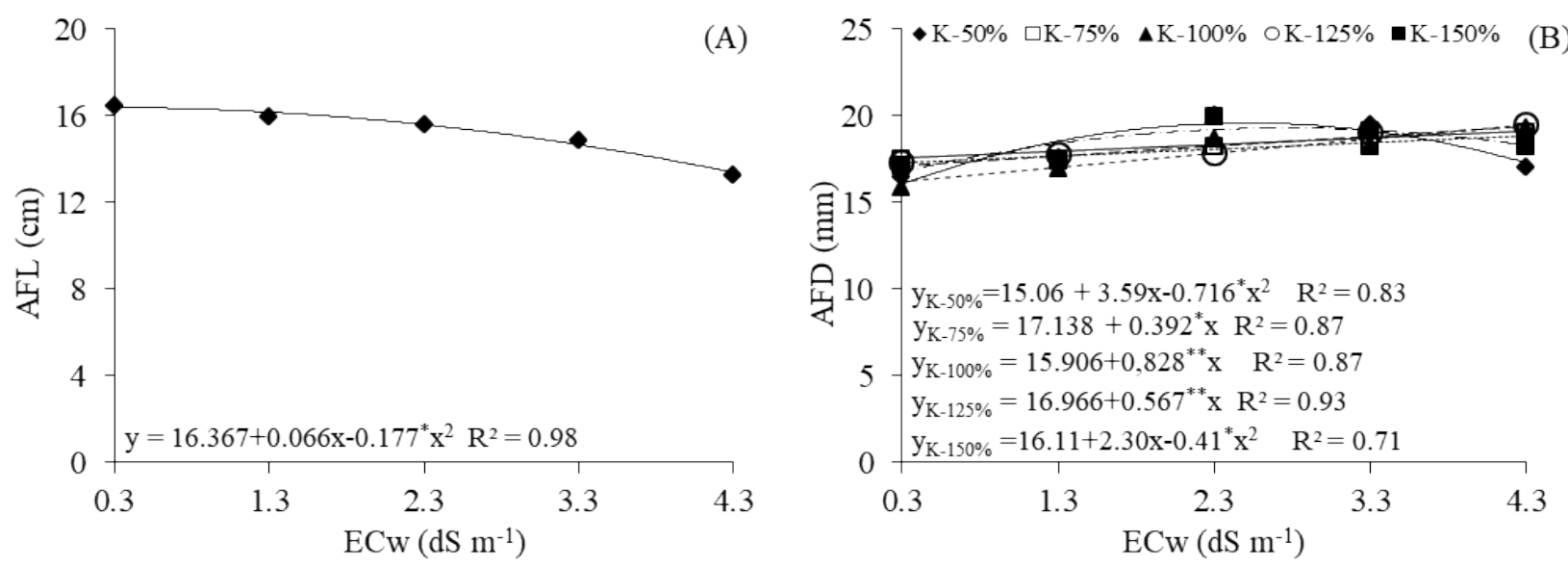

Figure 2. Average fruit weight (AFW) of okra as a function of the electrical conductivity of irrigation water (ECW). Pombal, PB.

The evaluation of the lactic fermentation of okra fruits, based on titratable acidity, soluble solids, vitamin $\mathrm{C}$, soluble solids/titratable acidity ratio, and hydrogen potential, under the influence of $\mathrm{NaCl}$, $\mathrm{CaCl}_{2}$, and $\mathrm{KCl}$ mixtures, as well as the different salinity levels of irrigation water, are presented according to the analysis variance summary (Table
4), which shows that the salinity levels significantly influenced titratable acidity, vitamin $\mathrm{C}$, and soluble solids/titratable acidity ratio (SS/TA) $(\mathrm{p}<0.01)$. The brine formulations affected titratable acidity, soluble solids and ratio $(p<0.01)$. For the interaction between the factors (SL x F), there was a significant effect $(\mathrm{p}<0.01)$ only on the $\mathrm{pH}$ (Table 4$)$.

\section{Table 4}

Summary of the analysis of variance for titratable acidity (TA), soluble solids (SS), vitamin C (VitC), soluble solids/titratable acidity ratio (SS/TA), and hydrogen potential (pH) of fresh okra fruits subjected to different levels of irrigation water salinity and lactic fermentation brines. Pombal, PB

\begin{tabular}{lcccccc}
\hline \multirow{2}{*}{ Source of variation } & \multirow{2}{*}{ DF } & \multicolumn{5}{c}{ Mean squares } \\
\cline { 3 - 6 } & & TA & SS & VitC & SS/TA & pH \\
\hline Saline levels (S) & 4 & $0.004^{* *}$ & $0.053^{\text {ns }}$ & $26.346^{* *}$ & $3494.323^{* *}$ & $0.082^{* *}$ \\
$\quad$ Linear regression & 1 & $0.010^{* *}$ & $0.046^{\text {ns }}$ & $91.292^{* *}$ & $5744.016^{* *}$ & $0.111^{* *}$ \\
$\quad$ Quadratic regression & 1 & $0.001^{\text {ns }}$ & $0.103^{\text {ns }}$ & $11.396^{* *}$ & $1216.777^{* *}$ & $0.165^{\text {ns }}$ \\
Fermentation brines (F) & 5 & $0.002^{* *}$ & $9.339^{* *}$ & $0.335^{\text {ns }}$ & $3149,674^{* *}$ & $0.155^{\text {ns }}$ \\
Interaction (S x F) & 20 & $0.0009^{\text {ns }}$ & $0.260^{\text {ns }}$ & $0.616^{\text {ns }}$ & $802.174^{\text {ns }}$ & $0.205^{\text {ns }}$ \\
Repetition & 2 & $0.00008^{\text {ns }}$ & $0.318^{\text {ns }}$ & $1.072^{\text {ns }}$ & $312.054^{\text {ns }}$ & $0.353^{\text {ns }}$ \\
Residual & 58 & 0.0006 & 0.216 & 0.382 & 497.743 & 0,088 \\
CV (\%) & & 26.08 & 5.09 & 12.97 & 22.06 & 5.28 \\
Overall Average & & 0.095 & 9.155 & 4.768 & 101.149 & 5.640 \\
\hline
\end{tabular}

ns, $* *, *$ respectively not significant, significant at $\mathrm{p}<0.01$ and $\mathrm{p}<0.05$; DF -Degree of freedom; CV - Coefficient of variation. 
According to Figure 3A, titratable acidity (TA) showed a significant difference as a function of salinity levels, where the fruits of plants irrigated with a salinity of $0.3 \mathrm{dS} \mathrm{m}^{-1}$ obtained the highest TA, $0.11 \%$. In addition, the linear regression equation showed a reduction at ECw of $4.3 \mathrm{dS} \mathrm{m}^{-1}$ of $7.69 \%$ per unit increase in $\mathrm{ECW}$, that is, $30.76 \%$ reduction in the titratable acidity of okra fruits. The results confirmed that the use of saline waters improved okra quality characteristics such as titratable acidity (Figure 3A) and vitamin C (Figure 4A), since the values were between $0.11 \%$ and $0.08 \%$, similar to those obtained by Morais et al. (2017). These authors evaluated the postharvest quality of okra subjected to different salinity levels in the nutrient solution and obtained an average of $0.12 \%$ for 2.32 $\mathrm{dS} \mathrm{m} \mathrm{m}^{-1}$ of salinity in the nutrient solution.

According to the results of the means comparison test, referring to the brine formulations for titratable acidity after the preservation period (25 days), the formulations 2, 4, and 5, whose fermentation brines were prepared with $\mathrm{CaCl}_{2}, \mathrm{NaCl}: \mathrm{CaCl}_{2}$, and $\mathrm{CaCl}_{2}: \mathrm{KCl}$ in the proportions of $100 \mathrm{~g} \mathrm{~L}^{-1}, 50: 50 \mathrm{~g}$ $\mathrm{L}^{-1}$, and 50:50 $\mathrm{g} \mathrm{L}^{-1}$, resulted in titratable acidity of $0.09 \%, 0.11 \%$, and $0.10 \%$ citric acid, respectively (Figure 3B), indicating dependence of the titratable acidity present in okra fruits on the presence of $\mathrm{CaCl}_{2}$ in the brine formulation, intensifying the oxidation of organic acids in the tricarboxylic acid cycle due to fruit respiration (Silva, Morais, Rocha, Santos \& Sarmento, 2009). However, Figure 3B also shows reductions in fruit TA, especially for the formulations 1,3 , and 6 , which refer to fermentation in the presence of $100 \mathrm{~g} \mathrm{~L}^{-1} \mathrm{NaCl}, 100 \mathrm{~g} \mathrm{~L}^{-1} \mathrm{KCl}$, and $50 \mathrm{~g} \mathrm{~L}^{-1} \mathrm{NaCl}: 50 \mathrm{~g} \mathrm{~L}^{-1} \mathrm{KCl}$, with average titratable acidity of $0.08 \%$ citric acid. The reduction in acidity verified by titration is probably due to secondary fermentations that oxidize lactic acid, producing aroma compounds (Goldoni, 2007).
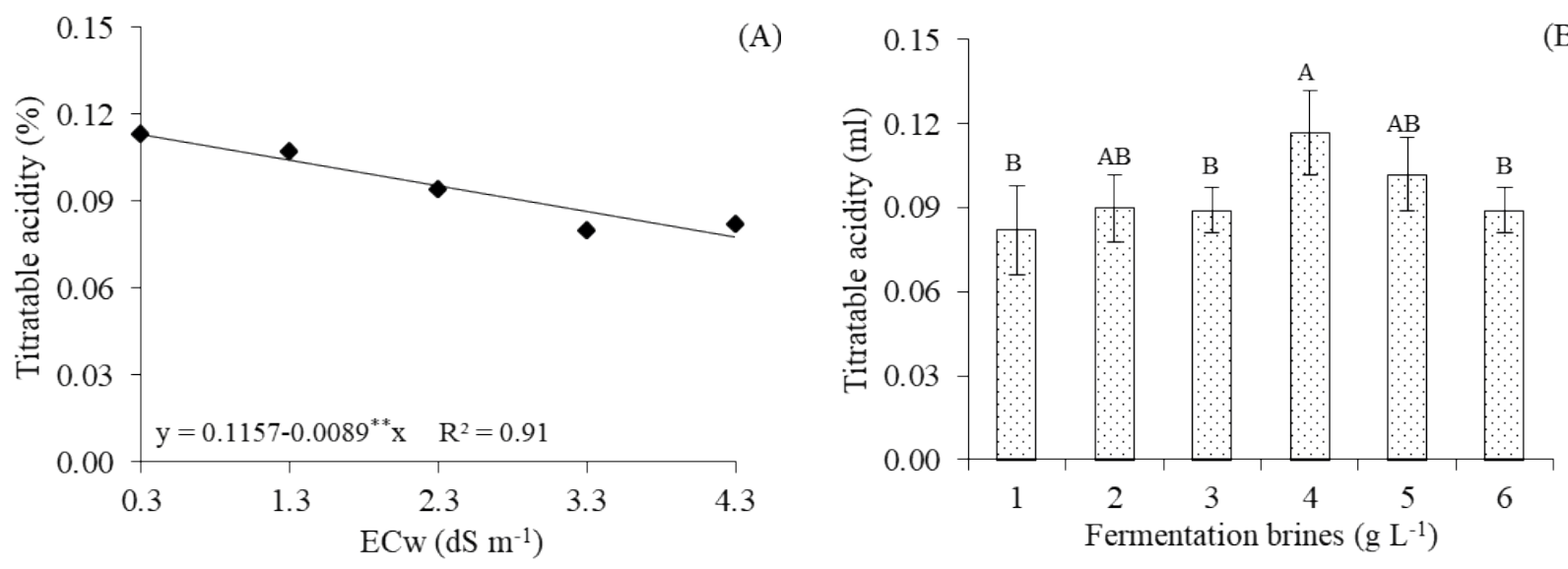

Figure 3. Titratable acidity of pickled okra fruits as a function of the electrical conductivity of irrigation water (ECw) (A) and lactic fermentation brines (B). Pombal, PB.

Vertical bars represent the standard error of the mean $(n=3)$. Means with different letters indicate that treatments differ from each other by the Tukey test $(\mathrm{p}<0.05)$.

The salt stress caused by irrigation had more pronounced effects on the vitamin $\mathrm{C}$ content of pickled okra fruits under irrigation with $4.0 \mathrm{dS} \mathrm{m}^{-1}$ water (Figure 4A), which resulted in higher vitamin

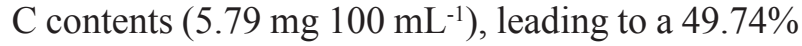
increase in the fruits of plants subjected to $\mathrm{ECw}$ of $0.3 \mathrm{dS} \mathrm{m} \mathrm{m}^{-1}$. It is known that the enrichment of salts in nutrient solution also increases the content 
of ascorbic acid, which adds acidic flavor to the fruit, because abiotic stresses, such as salt stress, induce oxidative damage, increasing the antioxidant

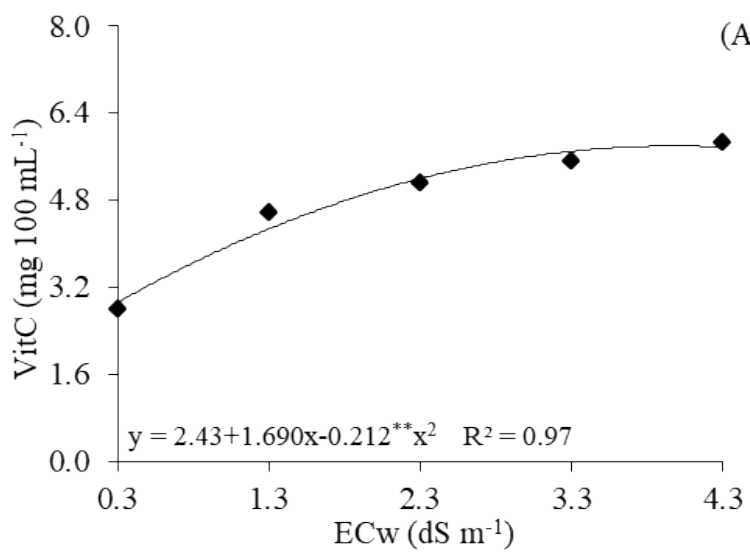

capacity of plants through a higher content of ascorbic acid (Altunkaya \& Gökmen, 2008; Xu et al., 2008).

Figure 4. Vitamin $\mathrm{C}(\mathrm{VitC})$ contents as a function of the electrical conductivity of irrigation water (ECw) (A) and soluble solids of pickled okra fruits as a function of lactic fermentation brines (B). Pombal, PB.

Vertical bars represent the standard error of the mean $(n=3)$. Means with different letters indicate that treatments differ from each other by the Tukey test $(\mathrm{p}<0.05)$.

By analyzing the soluble solids of okra fruits as a function of lactic fermentation brines (Figure 4B), it is observed that the fermentation brine formulated with the presence of the two components (F4 $\mathrm{NaCl}: \mathrm{CaCl}_{2}$ ) in the mixture proportion of $50: 50$ $\mathrm{g} \mathrm{L}^{-1}$ resulted in greater accumulation of soluble solids, $9.96^{\circ}$ Brix, but it did not differ from F1 - 100 $\mathrm{g} \mathrm{L}^{-1} \mathrm{NaCl}$ and $\mathrm{F} 2-100 \mathrm{~g} \mathrm{~L}^{-1} \mathrm{CaCl}_{2}$, with values of 9.58 and $9.86{ }^{\circ}$ Brix, respectively. It was also verified that fermentation with formulation 3 (100 $\mathrm{g} \mathrm{L}^{-1} \mathrm{KCl}$ ) led to reductions in soluble solids, with a decrease of $20.38 \%$ when compared to formulation 4. The results obtained are higher than those found by Santos, Pereira, Medeiros, Costa and Pereira (2019), who evaluated the production and quality of okra fruits produced with mineral and organic fertilization and observed soluble solids contents ranging between 5.81 and $5.93{ }^{\circ}$ Brix of fresh okra fruits. Therefore, it can be inferred that the adoption of lactic fermentation in okra fruits improved a sensory attribute (total soluble solids content) because, during the process of obtaining fermented pickles, lactic bacteria produce organic acids, aldehydes, ketones, and other organic compounds that confer special sensory characteristics to this product (Lima et al., 2006).

For the soluble solids/titratable acidity ratio (SS/ $\mathrm{TA})$ as a function of the levels of irrigation water salinity (Figure 5A), the regression equation shows that it was influenced by the salinity of irrigation water, increasing up to the level of $2.7 \mathrm{dS} \mathrm{m}^{-1}$, with a ratio of 113.6, and decreasing significantly from this level as the effects of salinity intensified. Low ratio values are attributed to high contents of $\mathrm{Na}^{+}$and $\mathrm{Cl}^{-}$ in leaf tissues, which may have inhibited the activity of organic compounds in plants, directly influencing the qualitative attributes of fruits, such as soluble solids and ratio (Andrade \& Andrade, 2004). 

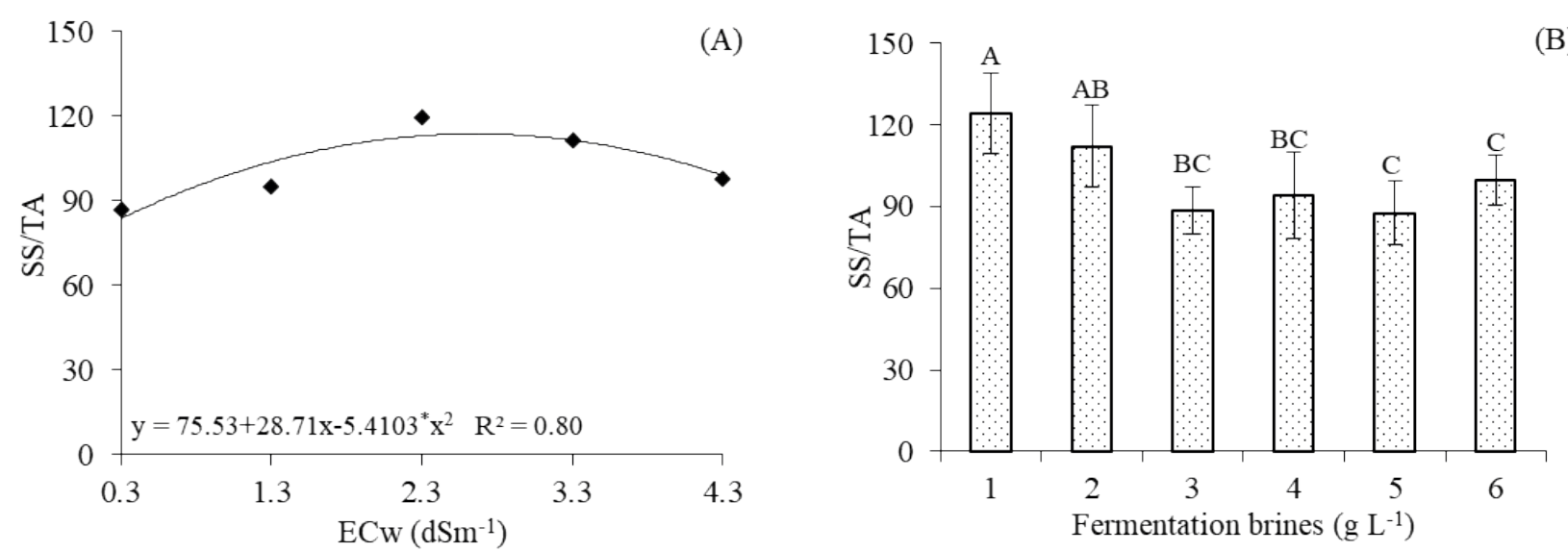

Figure 5. Soluble solids/titratable acidity ratio (SS/TA) of pickled okra fruits as a function of the electrical conductivity of irrigation water (ECw) (A) and lactic fermentation brines (B). Pombal, PB.

Based on the comparative data between means for ratio as a function of lactic fermentation brines (Figure 5B), fruits subjected to formulations F1 $100 \mathrm{~g} \mathrm{~L}^{-1} \mathrm{NaCl}$ and $\mathrm{F} 2-100 \mathrm{~g} \mathrm{~L}^{-1} \mathrm{CaCl}_{2}$ had the highest values of soluble solids/titratable acidity ratio, 124.33 and 112.28 , respectively, maintaining the trend already observed for soluble solids. This ratio is one of the best ways of evaluating the degree of sweetness of the product, but it can be influenced by the fruit maturity stage and crop management conditions, and reflects the possible abiotic stresses during fruit formation (Silva et al., 2008).

The increase in irrigation water salinity reduced the $\mathrm{pH}$ of pickled okra fruits (Figure 6). According to the regression equations, the linear model indicates $\mathrm{pH}$ reductions of $1.14 \%$ per unit increase in the levels of irrigation water salinity, i.e., a $4.59 \%$ decrease in plants irrigated with $4.3 \mathrm{dS} \mathrm{m}^{-1}$ water compared to those irrigated with $\mathrm{ECw}$ of $0.3 \mathrm{dS}$ $\mathrm{m}^{-1}$. Compared to the $\mathrm{pH}$ obtained in fruits under different water salinities and storage times, the values were lower than the 6.27 obtained by Oliveira et al. (2012). The accumulation of salts in plant tissues caused by ECw from 0.3 to $4.3 \mathrm{dS} \mathrm{m}^{-1}$ led to a reduction of $\mathrm{pH}$ in pickled okra fruits, increasing their acidic character. This can be attributed to metabolic transformations, possibly resulting in the appearance of the characteristic flavor, due to the transformation of starch into soluble sugars, and the accumulation of total acids, which resulted in a higher concentration of hydrogen ions (Lucena, 2006). 


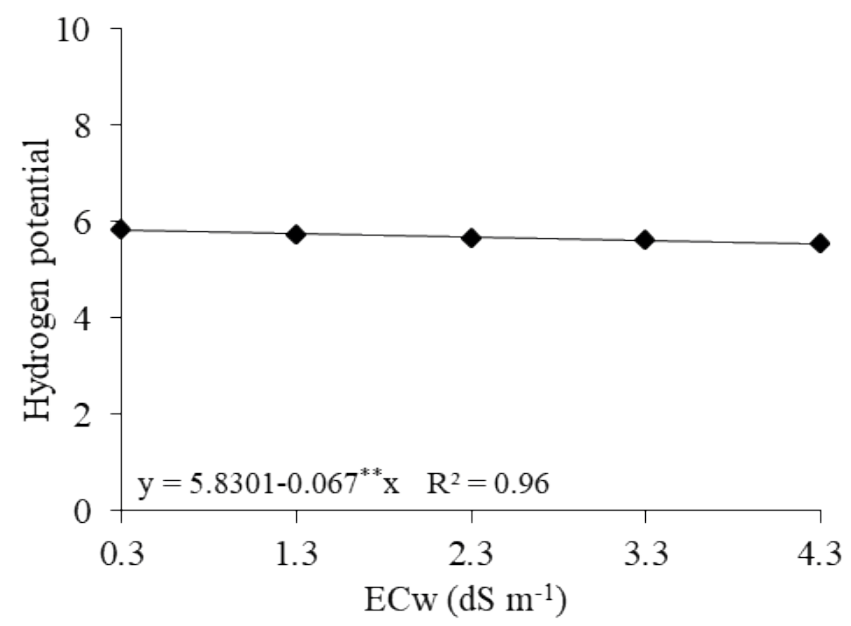

Figure 6. Hydrogen potential $(\mathrm{pH})$ of pickled okra fruits as a function of the electrical conductivity of irrigation water (ECw). Pombal, PB.

\section{Conclusions}

Irrigation water salinity negatively affected the average length, average weight, titratable acidity, soluble solids / titratable acidity ratio, and hydrogen potential of okra fruits.

Potassium doses cause increments in the average diameter of okra fruits, minimizing the deleterious effects of irrigation water salinity.

The vitamin $\mathrm{C}$ content of pickled okra fruits were not compromised by salt stress.

Among the lactic fermentation brines, the formulation containing the proportion of $\mathrm{NaCl}: \mathrm{CaCl}_{2}$ stands out with the highest titratable acidity and soluble solids in pickled okra fruits.

\section{References}

Abbasi, G. H., Akhtar, J., Haq, M. A., Ali, S., Chen, Z. H., \& Malik, W. (2014). Exogenous potassium differentially mitigates salt stress in tolerant and sensitive maize hybrids. Pakistan Journal of Botany, 46(1), 135-146.

Abubaker, B. M. A., Ahadi, M., Shuang-En, Y., \& GuangCheng, S. (2014). Different irrigation methods for okra crop production under semi-arid conditions. International Journal of Engineering Research and Technology, 3(4), 787-794.
Altunkaya, A., \& Gökmen, V. (2008). Effect of various inhibitors on enzymatic browning, antioxidant activity and total phenol content on fresh lettuce (Lactuca sativa). Food Chemistry, 107(3), 11731179. doi: 10.1016/j.foodchem.2007.09.046

Andrade, J. M. B., \& Andrade, A. B. (2004). Características físico-químicas do maracujá amarelo produzido em diferentes épocas em Marumbi-PR. Arquivo Apadec, 1(8), 391-396. doi: 10.1590/S0100204X 1999001200023

Azeem, A., Wu, Y., Xing, D., Javed, Q., \& Ullah, I. (2017). Photosynthetic response of two okra cultivars under salt stress and re-watering. Journal of Plant Interactions, 12(1), 67-77. doi: 10.1080/ 17429145. 2017.1279356

Bautista-Gallego, J., López-López, A., \& GarridoFernández, A. (2011). Effect of chloride salt mixtures on selected attributes and mineral content of fermented cracked aloreña. LWT - Food Science and Technology, 44(1), 120-129. doi: 10.1016/j. lwt.2010.06.027

Biswas, A., Hossain, M. M., Alam, Z., Islam, M. M., \& Biswas, A. (2016). Nutritive value and yield potential of okra (Abelmoschus esculentus L. Moench) genotypes. Bangladesh Journal of Agricultural Research, 41(3), 541-554. doi: 10.3329/ bjar.v41i3.29725

Di Cagno, R., Coda, R., De Angelis, M., \& Gobbetti, M. (2013). Exploitation of vegetables and fruits through lactic acid fermentation. Food Microbiology, 33(1), 1-10. doi: 10.1016/j.fm.2012.09.003 
Dias, N. S., Lira, R. B., Brito, B. L., Sousa, O. N., Neto, Ferreira, M., Neto, \& Oliveira, A. M. (2011). Produção de melão rendilhado em sistema hidropônico com rejeito da dessalinização de água em solução nutritiva. Revista Brasileira de Engenharia Agrícola e Ambiental, 14(7), 755-761. doi: 10.1590/ S1415-43662010000700011

Ferreira,D.F.(2011). Sisvar: a computer statistical analysis system. Ciência e Agrotecnologia, 35(6), 1039-1042. doi: 10.1590/S1413-70542011000600001

Finger, F. L., Della-Justina, M. E., Casali, V. W. D., \& Puiatti, M. (2008). Temperature and modified atmosphere affect the quality of okra. Scientia Agricola, 65(4), 360-364. doi: 10.1590/S010390162008000400006

Food and Agriculture Organization of the United Nations (2017). On Line and Multilingual Database. Recuperado de http://www.fao.org/faostat/en/\#data/ PP

Freitas, T. K. F. S., Oliveira, V. M., Souza, M. T. F., Geraldino, H. C. L., Almeida, V. C., Fávaro, S. L., \& Garcia, J. C. (2015). Optimization of coagulationflocculation process for treatment of industrial textile wastewater using okra (A. esculentus) mucilage as natural coagulant. Industrial Crops and Products. 76(s.n.), 538-544. doi: 10.1016/j. indcrop.2015.06.027

Garg, N., \& Bhandari, P. (2016). Interactive effects of silicon and arbuscular mycorrhiza in modulating ascorbate-glutathione cycle and antioxidant scavenging capacity in differentially salt-tolerant Cicer arietinum L. genotypes subjected to longterm salinity. Protoplasma, 253(9), 1325-1345. doi: 10.1007/s00709-015-0892-4

Goldoni, C. L. (2007). Aperfeiçoamento do processo de fermentação lática em diferentes hortaliças. Dissertação de mestrado, Universidade Estadual Paulista, Botucatu, SP, Brasil. Recuperado de https:// repositorio.unesp.br/handle/11449/90555

Islam, M. N., Islam, A., \& Biswas, J. C. (2017). Effect of gypsum on electrical conductivity and sodium concentration in salt affected paddy soil. International Journal of Agricultural Papers, 2(1), 19-23.

Li, D., Ni, K., Pang, H., Wang, Y., Cai, Y., \& Jin, Q. (2015). Identification and antimicrobial activity detection of lactic acid bacteria isolated from corn stover silage. Asian-Australasian Journal of Animal Sciences, 28(5), 620-631. doi: 10.5713/ajas.14.0439
Lima, A. S., Trancoso, F. O., Moura, K. M., Almeida, L. B., Silva, T. N. S., Souza, W. M., \& Marcellini, P. S. (2006). Caracterização centesimal de maxixe e sua aplicação na produção de picles. Alimentos $e$ Nutrição, 17(4), 407-412.

Lucena, E. M. P. (2006). Desenvolvimento e maturidade fisiológica de manga 'Tommy Atkins' no vale do São Francisco. Tese de doutorado, Universidade Federal do Ceará, Fortaleza, CE, Brasil. Recuperado de http://www.repositorio.ufc.br/handle/riufc/8383

Mandal, P. N., Singh, K. P., Singh, V. K., \& Roy, R. K. (2012). Effect of production and plant growth regulators on quality and economics of hybrid okra [Abelmoschus esculentus (L.) Moench]. Advance Research Journal of Crop Improvement, 3(1), 5-7.

Marschner, P. (2012). Mineral nutrition of higher plants (3nd ed.). San Diego, USA: Elsevier.

Medeiros, J. F., Duarte. S. R., Fernandes, P. D., Dias, N. da S., \& Gheyi, H. R. (2008). Crescimento e acúmulo de $\mathrm{N}, \mathrm{P}$ e $\mathrm{K}$ pelo meloeiro irrigado com água salina. Horticultura Brasileira, 26(4) 452-457. doi: 10.1590/S0102-05362008000400006

Mermoud, A., Tamini, T. D., \& Yacouba, H. (2005). Impact of different irrigation schedules on the water balance components of an onion crop in semi-arid zone. Agricultural Water Management, 77(1-3), 282-295. doi: 10.1016/j.agwat.2004.09.033

Morais, H. M., Neta, Diniz, A. A., Dias, N. S., Freitas, R. S., Oliveira, F. A., \& Melo, N. J. A. (2017). Qualidade de quiabo cultivado em fibra de coco e fertirrigado com soluções nutritivas salinas. Anais do Simpósio de Manejo de Solo e Água, Mossoró, RN, Brasil, 1.

Mota, W. F., Finger, F. L., \& Casali, V. W. D. (2000). Olericultura: melhoramento genético do quiabeiro. Viçosa, MG: UFV, Departamento de Fitotecnia.

Neves, A. L. R., Lacerda, C. F., Guimarães, F. V. A., Hernandez, F. F. F., Silva, F. B., Prisco, J. T., \& Gheyi, H. R. (2009). Acumulação de biomassa e extração de nutrientes por plantas de feijão-de-corda irrigadas com água salina em diferentes estádios de desenvolvimento. Revista Ciência Rural, 39(3), 758765. doi: 10.1590/S0103-84782009005000014

Nguyen, N., Dong, N., Nguyen, H., \& Lee, P. (2015). Lactic acid bacteria: promising supplements for enhancing the biological activities of Kombucha. Springerplus, 4(91), 1-6. doi: 10.1186/s40064-0150872-3 
Novais, R. F., Neves, J. C. L., \& Barros, N. F. (1991). Ensaio em ambiente controlado. In A. J. Oliveira, W. E. Garrido, J. D. Araújo \& S. Lourenço (Eds.), Métodos de pesquisa em fertilidade do solo (pp. 189254). Brasília: EMBRAPA-SEA.

Oliveira, D. F., Mugridge, A., Chaves, A. R., Mascheroni, R. H., \& Viña, S. Z. (2012). Quality attributes of okra (Abelmoschus esculentus L. Moench) pods as affected by cultivar and fruit size. Journal of Food Research, 1(4), 224-235. doi: 10.5539/jfr.v1n4p224

Richards, L. A. (1954). Diagnostico y rehabilitacion de suelos salinos y sódicos (6a ed.). (Manual de Agricultura, 60). México: Limusa.

Santos, H. C., Pereira, E. M., Medeiros, R. L. S., Costa, P. M. A., \& Pereira, W. E. (2019). Production and quality of okra produced with mineral and organic fertilization. Revista Brasileira de Engenharia Agrícola e Ambiental, 23(2), 97-102. doi: 10.1590/1807-1929/agriambi.v23n2p97-102
Silva, F. F., Pereira, M. G., Ramos, H. C. C., Damasceno, P. C., Jr., Pereira, T. N. S., Gabriel, A. P. C., Ferreguetti, G. A. (2008). Selection and estimation of the genetic gain in segregating generations of papaya (Carica papaya L.). Crop Breeding and Applied Biotechnology, 8(3), 1-8. doi: 10.12702/1984-7033. v08n01a01

Silva, G. G., Morais, P. L. D., Rocha, R. H. C., Santos, E. C., \& Sarmento, J. D. A. (2009). Caracterização do fruto de cajaranazeira em diferentes estádios de maturação. Revista Brasileira de Produtos Agroindustriais, 11(2), 159-163. doi: 10.15871/15178595/rbpa.v11n2p159-163

Strohecker, R., \& Henning, H. M. (1967). Análises de vitaminas: métodos comprovados. Madrid: Paz Montolvo.

Xu, G., Liu, D., Chen, J., Ye, X., Ma, Y., \& Shi, J. (2008). Juice components and antioxidant capacity of citrus varieties cultivated in China. Food Chemistry, 106(2), 545-551. doi: 10.1016/j.foodchem.2007. 06.046 